\title{
Rapid Detection of Xanthomonas citri pv. fuscans and Xanthomonas phaseoli pv. phaseoli in Common Bean by Loop-Mediated Isothermal Amplification
}

\author{
Bruna Alicia Rafael de Paiva, ${ }^{1}$ Adriane Wendland, ${ }^{2,}{ }^{+}$Nara Cristina Teixeira, ${ }^{2}$ and Marisa A. S. V. Ferreira ${ }^{1}$ \\ ${ }^{1}$ Department of Plant Pathology, University of Brasilia, 70910-900 Brasilia, Distrito Federal, Brazil \\ ${ }^{2}$ Embrapa Arroz e Feijão, 75375-000 Santo Antônio de Goiás, Goiás, Brazil
}

\begin{abstract}
A single loop-mediated isothermal amplification (LAMP) assay was developed for specific detection of both pathogens that cause bacterial blight in common bean, Xanthomonas phaseoli pv. phaseoli (Xpp) and Xanthomonas citri pv. fuscans (Xcf). The objective was to provide a simple, easy-to-use, specific, and sensitive method to investigate the presence of one or both pathogens in plant material and seeds for routine diagnosis. The detection limits for both pathogens were $10 \mathrm{CFU} / \mathrm{ml}$ for cell suspensions and $1 \mathrm{fg}$ of DNA, whereas in conventional PCR, the primers detected up to $10^{5} \mathrm{CFU} / \mathrm{ml}$ and $1 \mathrm{ng}$ of DNA. Specificity was confirmed by

pathogen could be detected from $4 \mathrm{~h}$ up to 15 days postinoculation, even before disease symptoms were visible. When the method was applied to bacterium detection (Xpp or Xcf) in seed lots from infected plants, the bacterium detection rate was $100 \%$ ( 24 of 24 ). The pathogens were detected in seeds incubated for just $1 \mathrm{~h}$ in saline solution $(0.85 \%)$, reducing the time needed for bacterium detection. The LAMP assay could be useful as a tool in bean bacterial blight management. Rapid and sensitive detection of bacteria in bean seed lots would reduce the risks of planting highly contaminated seeds in environments favorable to blight multiplication.
\end{abstract} testing DNA from bean leaves, other Xanthomonas species, common fungal and bacterial bean pathogens, and bacteria from the leaf microbiota. The method was tested with bean leaves inoculated with Xpp, and the
Keywords: common bacterial blight, prokaryotes, field crops, oilseeds and legumes, pathogen detection, Phaseolus vulgaris $\mathrm{L}$
Common bacterial blight (CBB) is among the most destructive diseases of common bean, causing major losses in production, mainly in the rainy season when the environmental conditions (humidity and high temperature) are favorable for disease development and the spread of the pathogen (Vieira 1983). The disease is caused by four different genetic lineages belonging to two species within the genus Xanthomonas (Alavi et al. 2008; Schaad et al. 2005, 2006). The fuscans lineage and two nonfuscans lineages (NF2 and NF3) belong to the Xanthomonas citri pv. fuscans (Xcf) species (formerly Xanthomonas fuscans subsp. fuscans and Xanthomonas axonopodis pv. phaseoli group 9.6 by rep-PCR). The nonfuscans lineage (NF1) belongs to the Xanthomonas phaseoli pv. phaseoli (Xpp) species (formerly Xanthomonas axonopodis pv. phaseoli group 9.4 by rep-PCR) (Constantin et al. 2016; Rademaker et al. 2005).

The disease has been reported for the first time in Brazil in the state of Pará, and its causal agent was described as Xanthomonas campestris pv. phaseoli (Robbs 1954). The variant fuscans was later described in the state of São Paulo (Paradela Filho et al. 1967). The bacterium can survive and remain viable for periods of 5 to 15 years in bean seeds (Marques et al. 2005), and being carried in seeds is an important means of disease transmission over short and long distances. The disease is found worldwide, and it is the target of quarantine measures in many European countries, where it is not endemic. Thus, the

${ }^{\dagger}$ Corresponding author: A. Wendland; adriane.wendland@embrapa.br

Funding: This work was financed by Foundation for Research of the Federal District, Brazil grant 0193.000.959/2015 and Embrapa Arroz e Feijão. B. de Paiva was supported by a scholarship from the Conselho Nacional de Desenvolvimento Científico e Tecnológico.

*The $\boldsymbol{e}$-Xtra logo stands for "electronic extra" and indicates that three supplementary figures and two supplementary tables are published online.

The author(s) declare no conflict of interest.

Accepted for publication 12 July 2019.

(C) 2020 The American Phytopathological Society movement of contaminated seeds should be considered as a target to prevent pathogen spread worldwide.

According to the literature, different methods have been developed for diagnosis of $\mathrm{CBB}$, including the use of semiselective media (Claflin et al. 1987; Tebaldi et al. 2007), sorology (Maringoni et al. 1994), biochemical tests, and specific PCR. The specific primers X4c/X4e developed by Audy et al. (1994) amplify a 730-bp fragment of DNA that allows detection and identification of both fuscans and nonfuscans lineages. The primer pair Xf1/Xf2 was selected for specific detection of the fuscans lineage, and they amplify a DNA fragment of $450 \mathrm{bp}$ from all fuscans isolates tested (Toth et al. 1998).

Based on the sequences of virulence-associated genes avrBsT and xopL, Boureau et al. (2013) developed two pairs of primers $(\mathrm{Am} 1 \mathrm{~F} / \mathrm{R}$ and $\mathrm{Am} 2 \mathrm{~F} / \mathrm{R})$, which when used in conjunction with the primers $\mathrm{X} 4 \mathrm{c} / \mathrm{X} 4 \mathrm{e}$, composed a multiplex reaction. This would allow the differentiation of pathogenic and nonpathogenic isolates, decreasing the risk of false positives. The authors suggest that pathogenicity tests should be carried out for those results that are ambiguous.

The loop-mediated isothermal amplification (LAMP) assay was described by Notomi et al. (2000), and it became a tool for pathogen detection, including several species of the genus Xanthomonas (Hodgetts et al. 2015; Jun-hai et al. 2015; Lang et al. 2014; Palacio-Bielsa et al. 2015; Wang and Turechek 2016). In contrast to PCR, LAMP amplifies DNA at a single and constant temperature, and therefore, it does not require thermal cycler equipment, reducing costs and minimizing the time for pathogen detection.

LAMP assays require the Bst DNA polymerase enzyme (with strand displacement activity) and a set of four to six primers that hybridize in six to eight distinct regions of the target sequence, conferring high specificity. The amplification, in general, is completed under isothermal conditions between 60 and $65^{\circ} \mathrm{C}$, resulting in large quantities of amplified product in a short period (20 to $60 \mathrm{~min}$ ) (Jun-hai et al. 2015; Larrea-Sarmiento et al. 2018).

As the reaction progresses, the turbidity can be observed by using magnesium pyrophosphate, a by-product of the amplification reaction, which is directly related to the amount of amplified product (Arroyo et al. 2008). It is also possible to perform the visual 
detection by adding intercalating DNA dyes, such as ethidium bromide, SYBR Green, and propidium iodide, or indicators of metal ions, such as hydroxynaphythol blue and calcein. DNA intercalators must be added after the reaction and require ultraviolet (UV) illumination for visualization, and metal ion indicators are difficult to discern with the naked eye. When low concentrations of buffer are used in the reaction, a significant change from an initial alkaline $\mathrm{pH}$ to a final acidic $\mathrm{pH}$ makes it possible to add $\mathrm{pH}$ sensitive indicator dyes directly in the reaction for visualization (Tanner et al. 2015). The addition of $\mathrm{pH}$-sensitive indicator dyes before amplification also prevents aerosol contamination, which may result in false positives. This is a common problem when the amplification is verified by gel electrophoresis (Huang et al. 2017).

Considering that both species (Xpp and Xcf) cause similar symptoms and damage to the common bean, the objective of this work was to develop an LAMP method for the specific detection of the causal agents of bacterial blight in symptomatic and asymptomatic bean plants as well as seed lots originating from CBB-infected plants under field conditions.

\section{Materials and Methods}

Bacterial isolates and DNA isolation. The bacterial isolates used in this study were retrieved from the Collection of Multifunctional Microorganisms from Embrapa Arroz e Feijão, Brazil. Xpp and Xcf isolates were grown in 523 culture medium (Kado and Heskett 1970). Their identity was confirmed by specific PCR with X4c/ X4e primers (Audy et al. 1994) and Xf1/Xf2 (Toth et al. 1998) and pathogenicity assays on the susceptible bean cultivar BRS Ártico using the scissor method (Rava et al. 1988).

DNA was isolated from pure bacterial cultures using the Wizard Genomic DNA Purification Kit (Promega) following the manufacturer's instruction. DNA was quantified using NanoDrop 2000/c Spectrophotometers (Thermo Fisher Scientific).

Conventional PCR. The reaction was performed using the QIAGEN multiplex PCR Kit in a final volume of $10 \mu$ containing $5 \mu l$ of the master mix, $1 \mu \mathrm{l}$ of Q solution, $0.1 \mu \mathrm{M}$ each primer (Xf1/Xf2 and $\mathrm{X} 4 \mathrm{c} / \mathrm{X} 4 \mathrm{e})$, and $1 \mu \mathrm{l}$ of bacterial cell suspension $\left(10^{7} \mathrm{CFU} / \mathrm{ml}\right)$. The PCR program consisted of an initial denaturation of $95^{\circ} \mathrm{C}$ for $15 \mathrm{~min}$ followed by 37 cycles of $94^{\circ} \mathrm{C}$ for $30 \mathrm{~s}, 65^{\circ} \mathrm{C}$ for $30 \mathrm{~s}$, and $72^{\circ} \mathrm{C}$ for $1 \mathrm{~min}$ and a final extension at $72^{\circ} \mathrm{C}$ for $10 \mathrm{~min}$. Subsequently, the PCR products $(5 \mu \mathrm{l})$ were separated by electrophoresis in $1.5 \%$ agarose gel in TBE (Tris-borate/EDTA) $1 \times$ buffer stained with GelRed $2 \times$, viewed under UV light, and photo-documented via a digital system (L-PIX Loccus).

Primer design and LAMP protocol. The sequence amplified by the X4c/X4e primers (Audy et al. 1994) was located in the plasmid pA complete sequence (accession number CP021013.1) and used to develop the LAMP primers. The PrimerExplorer V5 software (Eiken Chemical Co. Ltd.) was used for the design of four LAMP primers: two internal (FIP and BIP) and two external (F3 and B3) primers. The sequences of the selected primers are described in Table 1.

The concentration of the primers was optimized, and the reactions were conducted according to the protocol established by Tanner et al. (2015), containing $2 \times$ buffer solution $\left[10 \mathrm{mM}(\mathrm{NH} 4)_{2} \mathrm{SO}_{4}, 10 \mathrm{mM}\right.$ $\mathrm{KCl}, 8 \mathrm{mM} \mathrm{MgSO}$, $1.4 \mathrm{mM} \mathrm{dNTPs}$, and $0.1 \%$ (vol/vol) Tween20 , pH 8.6 to 8.8 adjusted with $1 \mathrm{M} \mathrm{KOH}$ ], $200 \mu \mathrm{M}$ neutral red dye, $\mathrm{pH} 7.8,0.2 \mu \mathrm{M}$ F3 and B3 (each), 1.6 $\mu \mathrm{M}$ FIP and BIP (each), $8 \mathrm{U}$ of $B s t$ DNA polymerase large fragment (Biolabs; New England), and $1 \mu \mathrm{l}$ of lysed bacterial cell suspension $\left(10^{7} \mathrm{CFU} / \mathrm{ml}\right)$ or DNA $(10 \mathrm{ng} / \mathrm{ml})$. The bacterial cells were lysed at $95^{\circ} \mathrm{C}$ for $5 \mathrm{~min}$ before PCR.

To find the optimal amplification temperature, which was $63^{\circ} \mathrm{C}$, the reaction was carried out in a thermocycler (BioRad Thermal Cycler) with a temperature gradient that ranged from 55 to $65^{\circ} \mathrm{C}$ for 1 h. Negative controls containing nuclease-free water were included in each assay, and the positive controls were DNA from two pathogenic isolates from common bean crops in Brazil, BRM 25302 (Xpp) and BRM 25304 (Xcf). The neutral red dye (Vetec) added in the reaction allowed the amplification to be monitored by observing color change to shades of pink for the positive samples and yellow for the negative samples (Alhassan et al. 2016; Poole et al. 2017).

Specificity and sensitivity of the LAMP assay. To determine the specificity of the LAMP protocol, the primers were initially tested with 18 isolates of Xpp and 27 isolates of Xcf collected from many different geographical regions of Brazil (Table 2) and later tested with different species of the genus Xanthomonas (Xanthomonas gardneri, Xanthomonas axonopodis pv. manihotis, Xanthomonas axonopodis pv. glycines, and Xanthomonas campestris pv. campestris), other bacterial and fungal pathogens of common bean (Curtobacterium flaccumfaciens pv. flaccumfaciens, Colletotrichum lindemuthianum, Fusarium solani, Fusarium oxysporum f. sp. phaseoli, Macrophomina phaseolina, and Pseudocercospora griseola), DNA extracted from bean leaves, and the epiphytic microbial population present in bean leaves. Healthy bean leaves were collected randomly from plants growing in the greenhouse and an experimental field trial. The leaves were immersed in sterile water $(10 \mathrm{ml})$ and macerated, and from this extract, $1 \mu \mathrm{l}$ was used directly in the LAMP reactions.

To determine the minimum detectable concentration, cell suspensions of BRM 25302 (Xpp) and BRM 25304 (Xcf) isolates were prepared in water, and the concentrations were adjusted to $10^{8} \mathrm{CFU} / \mathrm{ml}$ followed by 10 -fold serial dilutions up to $10 \mathrm{CFU} /$ $\mathrm{ml}$. Suspensions were then incubated at $95^{\circ} \mathrm{C}$ for $5 \mathrm{~min}$ for cell lysis. The limit of detectable DNA was also determined with $12 \mathrm{di}$ lutions of DNA from isolate BRM25302 at $100 \mathrm{ng} / \mu \mathrm{l}$. Each dilution was used in LAMP and conventional PCR with X4c/ $\mathrm{X} 4 \mathrm{e}$ primers to compare the sensitivity of the two techniques. To confirm the results, 12 replicates of each of the five lower dilutions (cells or DNA) were used.

Bacterial detection in symptomatic and asymptomatic inoculated bean leaves. To evaluate the potential of LAMP to detect latent infections, 10-day-old bean plants of the susceptible BRS Ártico were inoculated by the scissor method (Rava et al. 1988) with a $10^{7} \mathrm{CFU} / \mathrm{ml}$ cell suspension of the BRM 25302 isolate. Two leaves per plant were collected randomly at $4 \mathrm{~h}$ and $1,2,3,4,5,10$, and 15 days postinoculation (dpi). Leaves of healthy plants were collected before inoculation and used as negative controls. For each leaf, fragments of $\sim 0.5 \mathrm{~mm}^{2}$ were removed from the inoculated area and macerated in microtubes containing $200 \mu \mathrm{l}$ of sterile water at room temperature. An aliquot of $1 \mu \mathrm{l}$ was used directly in the LAMP reactions.

LAMP detection of Xanthomonas spp. in bean seeds. A seed lot of cultivar BRS Esplendor was obtained from an experimental field planted at unfavorable climate conditions for $\mathrm{CBB}$ and showing no disease symptoms. A standard seed health test according to the International Rules for Seed Testing (ISTA) was performed to detect the presence of Xpp and Xcf. One thousand seeds were soaked in $0.85 \%$

Table 1. The sequences of the primers used in the PCR and loop-mediated isothermal amplification (LAMP) assays

\begin{tabular}{|c|c|c|}
\hline $\begin{array}{l}\text { Method } \\
\text { and } \\
\text { primer }\end{array}$ & Sequence $\left(5^{\prime} \rightarrow 3^{\prime}\right)$ & Reference \\
\hline \multicolumn{3}{|l|}{$\overline{\mathrm{PCR}}$} \\
\hline $\mathrm{X} 4 \mathrm{c}$ & GGCAACACCCGATCCCTAAACAGG & Audy et al. 1994 \\
\hline $\mathrm{X} 4 \mathrm{e}$ & CGCCGGAAGCACGATCCTCGAAG & Audy et al. 1994 \\
\hline Xf1.2 & ACGCAAGACCCATCGTCATTC & Toth et al. 1998 \\
\hline $\mathrm{Xf} 2.2$ & ATGGCTCAAGGAAAAACTTTCAGG & Toth et al. 1998 \\
\hline \multicolumn{3}{|c|}{ F } \\
\hline F3 & TCCATACCTTCGGTCAACGA & This study \\
\hline B3 & GCACCTCTTCGAGGATCGT & This study \\
\hline FIP & $\begin{array}{l}\text { TAGGCTCGGCCGCTCACTATCGTT } \\
\text { TTGAACGCCACCTGCTTTTCCT }\end{array}$ & This study \\
\hline BIP & $\begin{array}{l}\text { CAGCTTCCACACCACCAGCACGTT } \\
\text { TTCGGCGCGAAGGATGAC }\end{array}$ & This study \\
\hline
\end{tabular}


saline solution $(2 \mathrm{ml} / \mathrm{g})$ for $16 \mathrm{~h}$ at $4{ }^{\circ} \mathrm{C}$ followed by a serial dilution of 1 -ml aliquots of the seed-soaking extract, a colony count in agar medium, and identification by specific PCR as previously described (Grimault et al. 2014). Each dilution of the seed extract was plated four times.

Table 2. Identification, species, and genetic lineage of bacterial isolates used to evaluate the specificity of the loop-mediated isothermal amplification (LAMP) assay for detection of Xanthomonas phaseoli pv. phaseoli and Xanthomonas citri pv. fuscans

\begin{tabular}{|c|c|c|c|}
\hline Strains & Species & $\begin{array}{l}\text { Genetic } \\
\text { lineage }\end{array}$ & $\begin{array}{l}\text { LAMP } \\
\text { results }\end{array}$ \\
\hline BRM 25297 & X. phaseoli pv. phaseoli & NF1 & + \\
\hline BRM 25302 & X. phaseoli pv. phaseoli & NF1 & + \\
\hline BRM 25306 & $X$. phaseoli pv. phaseoli & NF1 & + \\
\hline BRM 25307 & X. phaseoli pv. phaseoli & NF1 & + \\
\hline BRM 25311 & X. phaseoli pv. phaseoli & NF1 & + \\
\hline BRM 25313 & $X$. phaseoli pv. phaseoli & NF1 & + \\
\hline BRM 25314 & $X$. phaseoli pv. phaseoli & NF1 & + \\
\hline BRM 25319 & X. phaseoli pv. phaseoli & NF1 & + \\
\hline BRM 25320 & $X$. phaseoli pv. phaseoli & NF1 & + \\
\hline BRM 25321 & X. phaseoli pv. phaseoli & NF1 & + \\
\hline BRM 25327 & $X$. phaseoli pv. phaseoli & NF1 & + \\
\hline BRM 25328 & $X$. phaseoli pv. phaseoli & NF1 & + \\
\hline BRM 25329 & X. phaseoli pv. phaseoli & NF1 & + \\
\hline BRM 25333 & X. phaseoli pv. phaseoli & NF1 & + \\
\hline BRM 25342 & $X$. phaseoli pv. phaseoli & NF1 & + \\
\hline BRM 48903 & $X$. phaseoli pv. phaseoli & NF1 & + \\
\hline BRM 48904 & $X$. phaseoli pv. phaseoli & NF1 & + \\
\hline BRM 48905 & $X$. phaseoli pv. phaseoli & NF1 & + \\
\hline BRM 32182 & $X$. citri pv. fuscans & NF2 & + \\
\hline BRM 32192 & $X$. citri pv. fuscans & NF2 & + \\
\hline BRM 32203 & $X$. citri pv. fuscans & NF2 & + \\
\hline BRM 32185 & X. citri pv. fuscans & NF2 & + \\
\hline BRM 32197 & $X$. citri pv. fuscans & NF2 & + \\
\hline BRM 32201 & X. citri pv. fuscans & NF2 & + \\
\hline BRM 48898 & X. citri pv. fuscans & NF2 & + \\
\hline BRM 48906 & $X$. citri pv. fuscans & NF2 & + \\
\hline BRM 48899 & $X$. citri pv. fuscans & NF3 & + \\
\hline BRM 48900 & $X$. citri pv. fuscans & NF3 & + \\
\hline BRM 48901 & $X$. citri pv. fuscans & NF3 & + \\
\hline BRM 48902 & X. citri pv. fuscans & NF3 & + \\
\hline BRM 25304 & $X$. citri pv. fuscans & Fuscans & + \\
\hline BRM 25308 & X. citri pv. fuscans & Fuscans & + \\
\hline BRM 25310 & $X$. citri pv. fuscans & Fuscans & + \\
\hline BRM 25316 & $X$. citri pv. fuscans & Fuscans & + \\
\hline BRM 25343 & X. citri pv. fuscans & Fuscans & + \\
\hline BRM 25347 & $X$. citri pv. fuscans & Fuscans & + \\
\hline BRM 25351 & $X$. citri pv. fuscans & Fuscans & + \\
\hline BRM 48912 & $X$. citri pv. fuscans & Fuscans & + \\
\hline BRM 48913 & $X$. citri pv. fuscans & Fuscans & + \\
\hline BRM 25359 & $X$. citri pv. fuscans & Fuscans & + \\
\hline BRM 48912 & $X$. citri pv. fuscans & Fuscans & + \\
\hline BRM 48913 & $X$. citri pv. fuscans & Fuscans & + \\
\hline BRM 48914 & $X$. citri pv. fuscans & Fuscans & + \\
\hline BRM 48915 & $X$. citri pv. fuscans & Fuscans & + \\
\hline BRM 48916 & $X$. citri pv. fuscans & Fuscans & + \\
\hline BRM 51627 & $X$. campestris pv. campestris & - & - \\
\hline BRM 51556 & $\begin{array}{l}X . \text { axonopodis } \\
\text { pv. manihotis }\end{array}$ & - & - \\
\hline BRM 51557 & $\begin{array}{l}X . \text { axonopodis } \\
\text { pv. glycines }\end{array}$ & - & - \\
\hline BRM 51628 & $X$. gardneri & - & - \\
\hline BRM 14933 & $\begin{array}{l}\text { Curtobacterium flaccumfaciens } \mathrm{pv} \text {. } \\
\text { flaccumfaciens }\end{array}$ & - & - \\
\hline BRM 15124 & Pseudocercospora griseola & - & - \\
\hline BRM 7447 & Colletotrichum lindemuthianum & - & - \\
\hline BRM 31143 & Fusarium solani & - & - \\
\hline BRM 14990 & Fusarium oxysporum f. sp. phaseoli & - & - \\
\hline BRM 32281 & Macrophomina phaseolina & - & - \\
\hline
\end{tabular}

After the healthy status of the seeds was confirmed, a subsample was artificially inoculated by spraying a bacterial suspension $\left(10^{8}\right.$ $\mathrm{CFU} / \mathrm{ml}$ ) of the BRM 25302 isolate over the seeds until they were completely covered. The seeds were left to dry under laminar flow. The sensitivity of the LAMP assay for detecting levels of contamination of 0.1 and $1 \%$ (1:999 and 10:990, respectively) was tested. The seeds were soaked in saline solution for $16 \mathrm{~h}$, and a 1-ml aliquot of the extract was centrifuged for $10 \mathrm{~min}$ at $12,000 \mathrm{rpm}$; the pellet was resuspended in $100 \mu \mathrm{l}$ of sterile water, and an aliquot of $1 \mu \mathrm{l}$ was used for the LAMP reactions.

To verify LAMP efficiency compared with the standard ISTA method, seed lots of 24 cultivars/lineages of common beans showing high incidence of CBB were used. One pathogen-free lot was used as a negative control. Each seed lot was subjected to the conventional ISTA detection method, and then, an aliquot of each crude extract was used for LAMP. In all assays, a positive control, which was a bacterial suspension of isolate BRM 25302, and a water negative control were included.

To reduce the time needed for detection, samples of 1,000 bean seeds were soaked in saline solution for 1 and $4 \mathrm{~h}, 1 \mathrm{ml}$ of solution was centrifuged, and the pellet was resuspended in water $(100 \mu \mathrm{l})$. Aliquots of $1 \mu l$ were used for the LAMP reactions.

\section{Results}

Specificity and sensitivity of the LAMP assay. The LAMP reaction conditions (temperature and time) were optimized for $63^{\circ} \mathrm{C}$ for $60 \mathrm{~min}$. The limits of LAMP detection were $10 \mathrm{CFU} / \mathrm{ml}$ for cell suspensions and $1 \mathrm{fg}$ for DNA (Fig. 1), which were confirmed with 12 replicates of each of the five lower dilutions (Supplementary Figs. S1 and S2). Conventional PCR, with primers X4c/X4e (Audy et al. 1994) (Table 1), was less sensitive, detecting up to $10^{5} \mathrm{CFU} / \mathrm{ml}$ and $1 \mathrm{ng}$ of DNA. Because the same results were obtained for both species, only the results obtained for Xpp are presented.

The specificity of the LAMP assay was tested with other pathogens associated with common bean, bacteria isolated from bean leaves, bean DNA, and other species of the genus Xanthomonas. Only samples containing DNA from Xpp developed a pink coloration after the reaction. Samples containing only water, bean DNA, and DNA and cells from other pathogens or microorganisms showed a yellow color after the reaction, indicating that there was no DNA amplification (Fig. 2).

Bacterial detection in symptomatic and asymptomatic inoculated bean leaves. To demonstrate its applicability, the LAMP method was tested with samples collected from inoculated bean leaves before and after disease symptoms were visible. The leaves began to show symptoms 4 dpi (Table 4); however, the presence of bacteria was detected by LAMP at all evaluation times from $4 \mathrm{~h}$ after inoculation until the end of the evaluation time at $15 \mathrm{dpi}$. This demonstrated the potential of the LAMP assay for the detection of the CBB pathogens in latent infections (Fig. 3).

LAMP detection of Xanthomonas spp. in bean seeds. The LAMP assay was tested with 24 bean seed lots collected from an experimental field with bacterial blight. The rate of pathogen detection was $100 \%$ with the LAMP method. Compared with the ISTA standard method, the same seed lots showed a lower detection rate of 18 of 24 (75\%) (Supplementary Table S1). Pathogen detection by LAMP was achieved even when the time needed for seed soaking in saline was reduced from $16 \mathrm{~h}$ (ISTA method) to 1 or $4 \mathrm{~h}$. The LAMP assay also detected contamination rates of $1.0 \%$ (10 of 1,000 seeds) and $0.1 \%$ ( 1 of 1,000 seeds) (Fig. 4).

\section{Discussion}

The diagnosis of CBB in common bean is based on a set of complementary methods, such as recognition of symptoms, use of semiselective medium for bacterial isolation (Claflin et al. 1987; Tebaldi et al. 2007), biochemical tests (Ryu 1940; Schaad et al. 2001), pathogenicity tests (Rava et al. 1988), and molecular methods based on PCR (Audy et al. 1994; Boureau et al. 2013; Toth et al. 1998), which are often time consuming. In this study, an LAMP assay was 
developed for rapid detection of Xpp and Xcf in leaves and seeds of common beans.

LAMP assays can be used for the detection of plant pathogens, with numerous advantages in relation to other techniques. LAMP reactions show high sensitivity and speed, and the results can be seen with the naked eye with the addition of dyes, without the need for postamplification procedures, such as gel electrophoresis.

All parameters for detection were optimized, and the assay can be successfully performed using a water bath or any another heating device at a constant temperature of $63^{\circ} \mathrm{C}$. The neutral red dye allowed the visualization of the reactions, which were pink for the positive samples and yellow for the negative ones; these results were confirmed by quantitative measurements with a DR2800 spectrophotometer (Hach) (Supplementary Table S2). It is important to emphasize that it is preferable to add contrast dyes before the amplification and that detection should be performed in a closed tube to reduce the risk of cross-contamination by aerosols, producing false positives.

In the sensitivity tests, the LAMP assay showed a detection limit of $1 \mathrm{fg}$ of target DNA or $10 \mathrm{CFU} / \mathrm{ml}$ bacterial suspension, lower than the limits of conventional PCR ( $1 \mathrm{ng}$ and $10^{5} \mathrm{CFU} / \mathrm{ml}$, respectively) (Table 3). It is possible that this high sensitivity is because of the target sequence being repetitive and present in both the plasmid and the chromosome (Audy et al. 1994; Gilbertson et al. 1989), which gives a larger amount of the target sequence per cell. Similar sensitivity levels were reported for other plant pathogenic bacteria, such as Erwinia amylovora (Bühlmann et al. 2013), Ralstonia solanacearum (Lenarčič et al. 2014), and Xanthomonas albilineans (Dias et al. 2018). The specificity of the LAMP assay was validated with other Xanthomonas species, seven other pathogens of common bean, and the leaf epiphytic population, which showed that it was highly specific to the target organisms.
Sensitive and specific detection of pathogens is very important for disease diagnosis, prediction, and control. The developed LAMP assay allowed the bacterium to be detected in symptomatic and latent

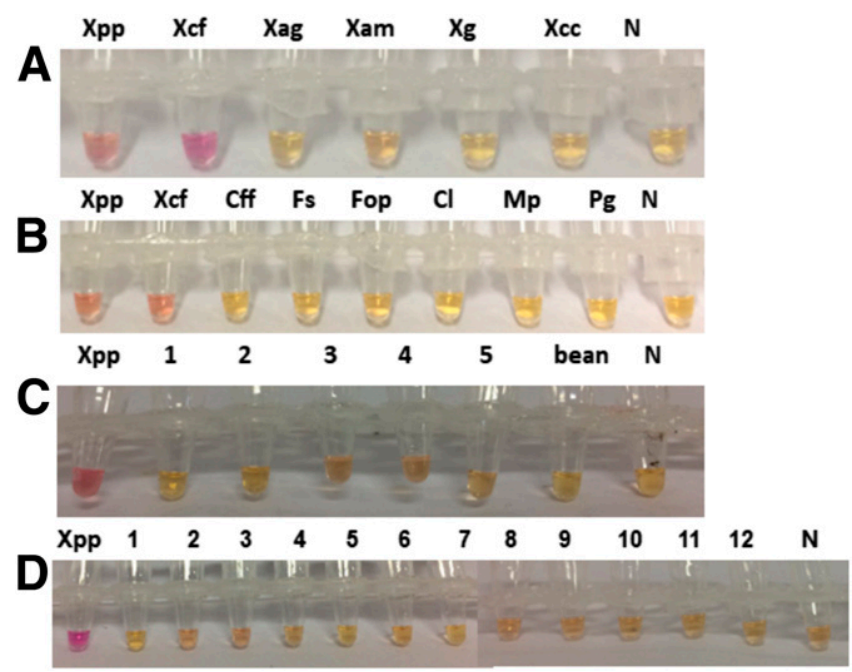

Fig. 2. Specific detection of Xanthomonas phaseoli pv. phaseoli (Xpp) and Xanthomonas citri pv. fuscans (Xcf) by loop-mediated isothermal amplification. A, N negative control; Xag, Xanthomonas axonopodis pv. glycines; Xam, Xanthomonas axonopodis pv. manihotis; Xcc, Xanthomonas campestris pv. campestris; $\mathrm{Xg}$, Xanthomonas gardneri. B, Cff, Curtobacterium flaccumfaciens pv. flaccumfaciens; $\mathrm{Cl}$ Colletotrichum lindemuthianum; Fop, Fusarium oxysporum f. sp. phaseoli; Fs, Fusarium solani; Mp, Macrophomina phaseolina; Pg, Pseudocercospora griseola. C, Lanes 1 to 5, microbiota from bean leaves (greenhouse); bean, DNA extracted from bean leaves. D, Lanes 1 to 12, microbiota from bean leaves (field).

A

\begin{tabular}{|c|c|c|c|c|c|c|c|c|c|}
\hline \multirow{2}{*}{ Method } & \multicolumn{9}{|c|}{$\mathrm{CFU} / \mathrm{ml}$} \\
\hline & $10^{8}$ & $10^{7}$ & $10^{6}$ & $10^{5}$ & $10^{4}$ & $10^{3}$ & $10^{2}$ & $10^{1}$ & $\mathrm{~N}$ \\
\hline & & 7 & & & 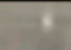 & & 7 & 7 & \\
\hline LAMP & & & & & & I & & & \\
\hline $\begin{array}{c}\text { Conventiona } \\
\mathrm{PCR}^{1}\end{array}$ & & & & & & & & & \\
\hline
\end{tabular}

B

\begin{tabular}{lllllllllll}
\hline \multirow{2}{*}{ Method } & \multicolumn{10}{c}{ [DNA] } \\
\cline { 2 - 9 } & $10 \mathrm{ng}$ & $1 \mathrm{ng}$ & $100 \mathrm{pg}$ & $10 \mathrm{pg}$ & $1 \mathrm{pg}$ & $100 \mathrm{fg}$ & $10 \mathrm{fg}$ & $1 \mathrm{fg}$ & $0.1 \mathrm{fg}$ & $\mathrm{N}$ \\
\hline & & & & & & & & & & \\
\multirow{2}{*}{ LAMP } & & & & & & & & & & \\
\end{tabular}

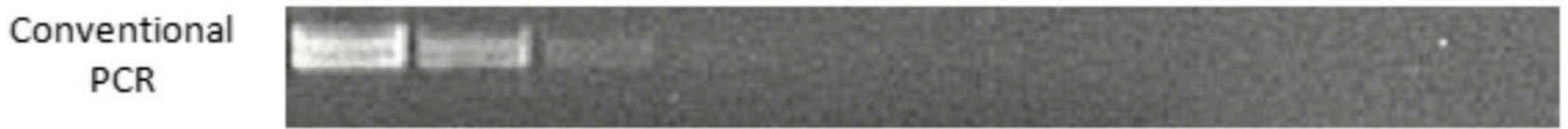

\footnotetext{
${ }^{1}$ Conventional PCR with specific primers X4c/X4e (Audy et al. 1994).
}

Fig. 1. Loop-mediated isothermal amplification (LAMP) and conventional PCR sensitivity evaluated by serial dilution of $A$, cell suspension $\left(10^{8}\right.$ to $\left.1 \mathrm{CFU} / \mathrm{ml}\right)$ and $B$, DNA (10 $\mathrm{ng}$ to $0.1 \mathrm{fg}$ ) from Xanthomonas phaseoli pv. phaseoli BRM 25302 isolate. N, negative control. 
infections, confirming the presence of the bacterium on the leaf tissue before the onset of the first symptoms. This demonstrates the effectiveness of the method for detecting the pathogen present in the plant tissue even at low concentrations, which may be applied for field samples.

Symptoms of CBB in the field are often visible on the leaves, and they are easy to recognize. However, when the seeds are contaminated, they rarely show any symptoms, making it difficult to test seed samples for the presence of bacteria with efficiency and precision. The method recommended by the ISTA allows for bacterial quantification, which is an advantage; however, it is time consuming and requires a skilled technician for bacterial isolation and identification. The LAMP assay developed in this study made it possible to detect the bacterium in the seeds with just $1 \mathrm{~h}$ of seed immersion in saline followed by $1 \mathrm{~h}$ of amplification by LAMP.

Seed contamination levels as low as $0.1 \%$ (that is, 1 contaminated seed in 999 healthy seeds) were detected by LAMP. When the method was tested in different samples of contaminated seeds, detection was $100 \%$ (24 of 24) against $75 \%$ (18 of 24) detection by the standard ISTA method. Similar detection rates were found by Lang et al. (2014) using specific LAMP primers for Xanthomonas oryzae pv. oryzae. The bacterium was detected in $100 \%$ of the evaluated samples, and a $0.5 \%$ detection rate in $5 \mathrm{~g}$ of seeds was obtained.

Six seed lots were negative for the ISTA method but positive for LAMP. The ISTA method is culture based; thus, it only detects viable and culturable cells. Several Xanthomonas species, such as X. campestris and Xanthomonas citri pv. citri, may enter the viable but not culturable (VBNC) state (Del Campo et al. 2009; Ghezzi and Steck 1999; Oliver 2005). It is not known whether the CBB pathogens may become unculturable. In this VBNC state, Xpp and Xcf cells would have been detected by LAMP but not by the standard culture-based method. However, the detection of DNA from unviable bacterial cells would also explain the positive result for LAMP and negative result for the ISTA method. This would represent a disadvantage of the LAMP assay. The use of DNA intercalants, such as propidium monoazide (PMA), has been proposed for LAMP and real-time PCR detection of foodborne and waterborne pathogens (Banihashemi et al. 2012) as well as plant pathogenic bacteria (Han et al. 2018; Temple et al. 2013). PMA binds to the chromosomal DNA of dead bacterial cells and therefore, blocks DNA amplification by PCR. If the VBNC state occurs in Xcf and Xpp from a commercial bean seed lot, then it is likely that the bacterial population can be underestimated by a culture-based method, which would result in false negatives. In that case, a modification would also be necessary in the LAMP assay to ensure that only DNA from viable cells is amplified.

Table 3. Limit of detection of Xanthomonas phaseoli pv. phaseoli cells by loop-mediated isothermal amplification (LAMP) and conventional PCR

\begin{tabular}{lcccccccc}
\hline & \multicolumn{7}{c}{ Bacterial cell suspensions (CFU/ml) } \\
\cline { 2 - 8 } Method $^{\mathrm{a}}$ & $\mathbf{1 0}^{\mathbf{7}}$ & $\mathbf{1 0}^{\mathbf{6}}$ & $\mathbf{1 0}^{\mathbf{5}}$ & $\mathbf{1 0}^{\mathbf{4}}$ & $\mathbf{1 0}^{\mathbf{3}}$ & $\mathbf{1 0}^{\mathbf{2}}$ & $\mathbf{1 0}^{\mathbf{1}}$ & $\mathbf{1 0}^{\mathbf{0}}$ \\
\hline LAMP & $+^{\mathrm{b}}$ & + & + & + & + & + & + & - \\
Conventional PCR & + & + & + & - & - & - & - & -
\end{tabular}

a Assays were repeated three times with the same results.

$\mathrm{b}+$, positive reaction; -, negative reaction.

Table 4. Detection of Xanthomonas phaseoli pv. phaseoli in symptomatic and asymptomatic common bean leaves before and after inoculation

\begin{tabular}{lccccccccc}
\hline & \multicolumn{10}{c}{ Days postinoculation } \\
\cline { 2 - 9 } & $\mathbf{- 1}$ & $\mathbf{0}$ & $\mathbf{1}$ & $\mathbf{2}$ & $\mathbf{3}$ & $\mathbf{4}$ & $\mathbf{5}$ & $\mathbf{1 0}$ & $\mathbf{1 5}$ \\
\hline LAMPa & - & + & + & + & + & + & + & + & + \\
Symptoms & - & - & - & - & - & + & + & + & + \\
\hline
\end{tabular}

${ }^{a}$ LAMP, loop-mediated isothermal amplification.
Some advantages of the LAMP method developed in this study are that it can be performed with minimum sample preparation, that there is no need for bacterial DNA extraction, and that the crude extract of seeds or leaves can be used directly in the reactions (Supplementary Fig. S3). Several studies demonstrate that LAMP tolerates higher levels of certain inhibitors and that sensitivity is less affected by the various plant compounds, allowing the DNA purification step to be omitted (Francois et al. 2011; Kaneko et al. 2007; Tomlinson et al. 2013).

The LAMP assay with visual detection designed for Xpp and Xcf shows simplicity, rapidity, sensitivity, and specificity as advantages. It could be potentially useful for screening bean seed lots, which would reduce the risk of introducing the pathogens in areas with environmental conditions favorable to their multiplication. Consequently, it would facilitate the decision to use preventive and control measures before the multiplication and dissemination of the pathogen(s) in the field.

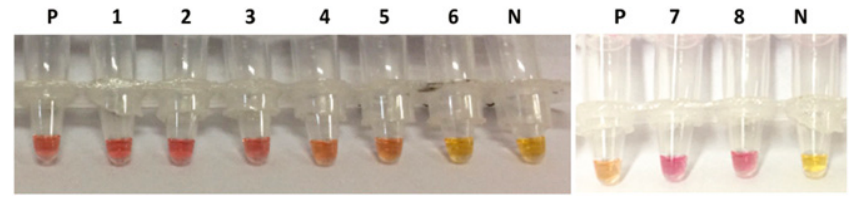

Fig. 3. Detection of Xanthomonas phaseoli pv. phaseoli by loop-mediated isothermal amplification in symptomatic and asymptomatic bean leaves after inoculation. The reactions were repeated twice. N, negative control; P, positive control; tube 1, 5 days postinoculation (dpi); tube 2, 4 dpi; tube 3, 3 dpi; tube 4, 2 dpi; tube 5, 1 dpi; tube 6, 1 day before the inoculation; tube 7, $10 \mathrm{dpi}$; tube 8,15 dpi.

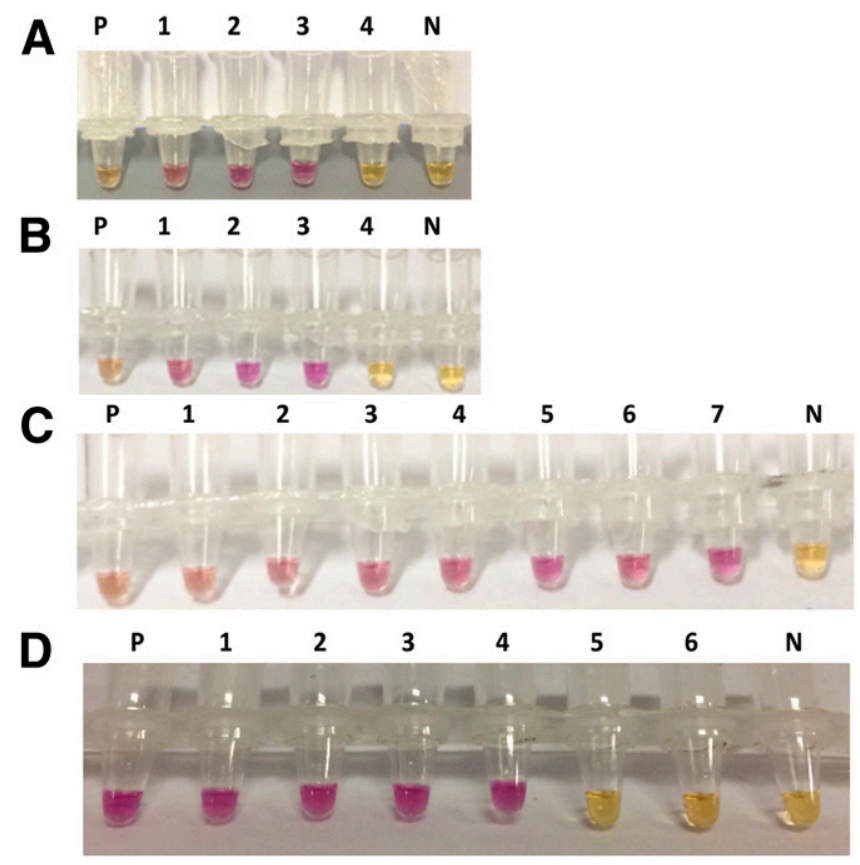

Fig. 4. Detection of Xanthomonas phaseoli pv. phaseoli by loop-mediated isothermal amplification in bean seed lots. A, Seeds maintained in saline solution for $1 \mathrm{~h}$. N, negative control; P, positive control; tubes 1, 2, and 3, contaminated seeds; tube 4 , healthy seeds. B, Seeds maintained in saline solution for $4 \mathrm{~h}$. Tubes 1, 2, and 3, contaminated seeds; tube 4, healthy seeds. $\mathrm{C}$, Seeds maintained for $1 \mathrm{~h}$ in saline solution. Tubes 1 to 7 , different lots of contaminated seeds. D, Healthy common bean seeds were mixed with seeds artificially inoculated with $X$. phaseoli pv. phaseoli at different levels of contamination in 1,000 seeds. Tubes 1 and 2, 1\% contamination (10 of 990); tubes 3 and $4,0.1 \%$ contamination ( 1 of 999 ); tubes 5 and $6,0 \%$ contamination $(0$ of 1,000$)$. 


\section{Literature Cited}

Alavi, S. M., Sanjari, S., Durand, F., Brin, C., Manceau, C., and Poussier, S. 2008. Assessment of the genetic diversity of Xanthomonas axonopodis pv. phaseoli and Xanthomonas fuscans subsp. fuscans as a basis to identify putative pathogenicity genes and a type III secretion system of the SPI-1 family by multiple suppression subtractive hybridizations. Appl. Environ. Microbiol. 74:3295-3301.

Alhassan, A., Osei-Atweneboana, M. Y., Kyeremeh, K. F., Poole, C. B., Li, Z., Tettevi, E., Tanner, N. A., and Carlow, C. K. S. 2016. Comparison of a new visual isothermal nucleic acid amplification test with PCR and skin snip analysis for diagnosis of onchocerciasis in humans. Mol. Biochem. Parasitol. 210:10-12.

Arroyo, M. I., Maestre, A., Carmona-Fonseca, J., Sosa, P. A., and Morales, G. P. 2008. Amplificación isotérmica de ácidos nucleicos tipo LAMP para la detección de Plasmodium: nueva técnica diagnóstica. Med. UIS. 21:158-175.

Audy, P., Laroche, A., Saindon, G., Huang, H. C., and Gilbertson, R. L. 1994. Detection of the bean common blight bacteria, Xanthomonas campestris pv. phaseoli and X. c. phaseoli var. fuscans, using the polymerase chain reaction. Phytopathology 84:1185-1192.

Banihashemi, A., Van Dyke, M. I., and Huck, P. M. 2012. Long-amplicon propidium monoazide-PCR enumeration assay to detect viable Campylobacter and Salmonella. J. Appl. Microbiol. 113:863-873.

Boureau, T., Kerkoud, M., Chhel, F., Hunault, G., Darrasse, A., Brin, C., Durand, K., Hajri, A., Poussier, S., Manceau, C., Lardeux, S., Saubion, S., and Jaques, M.-A. 2013. A multiplex-PCR assay for identification of the quarantine plant pathogen Xanthomonas axonopodis pv. phaseoli. J. Microbiol. Methods 92:42-50.

Bühlmann, A., Pothier, J. F., Rezzonico, F., Smits, T. H., Andreu, M., Boonham, N., Duffy, B., and Frey, J. E. 2013. Erwinia amylovora loop-mediated isothermal amplification (LAMP) assay for rapid pathogen detection and onsite diagnosis of fire blight. J. Microbiol. Methods 92:332-339.

Claflin, L., Vidaver, A., and Sasser, M. 1987. MXP, a semi-selective medium for Xanthomonas campestris pv. phaseoli. Phytopathology 77:730-734.

Constantin, E., Cleenwerck, I., Maes, M., Baeyen, S., Van Malderghen, C., De Vos, P., and Cottyn, B. 2016. Genetic characterization of strains named as Xanthomonas axonopodis pv. dieffenbachiae leads to a taxonomic revision of the $X$. axonopodis species complex. Plant Pathol. 65:792-806.

Del Campo, R., Russi, P., Mara, P., Mara, H., Peyrou, M., de León, I. P., and Gaggero, C. 2009. Xanthomonas axonopodis pv. citri enters the VBNC state after copper treatment and retains its virulence. FEMS Microbiol. Lett. 298:143-148.

Dias, V. D., Fernandez, E., Cunha, M. G., Pieretti, I., Hincapie, M., Roumagnac, P., Comstock, J. C., and Rott, P. 2018. Comparison of loop-mediated isothermal amplification, polymerase chain reaction, and selective isolation assays for detection of Xanthomonas albilineans from sugarcane. Trop. Plant Pathol. 43:1-9.

Francois, P., Tangomo, M., Hibbs, J., Bonetti, E. J., Boehme, C. C., Notomi, T., Perkins, M. D., and Schrenzel, J. 2011. Robustness of a loop-mediated isothermal amplification reaction for diagnostic applications. FEMS Immunol. Med. Microbiol. 62:41-48.

Ghezzi, J. I., and Steck, T. R. 1999. Induction of the viable but non-culturable condition in Xanthomonas campestris pv. campestris in liquid microcosms and sterile soil. FEMS Microbiol. Ecol. 30:203-208.

Gilbertson, R., Maxwell, D., Hagedorn, D., and Leong, S. 1989. Development and application of a plasmid DNA probe for detection of bacteria causing common bacterial blight of bean. Phytopathology 79:518-525.

Grimault, V., Olivier, V., Rolland, M., Darrasse, A., and Jacques, M.-A. 2014. Detection of Xanthomonas axonopodis pv. phaseoli and Xanthomonas axonopodis pv. phaseoli var. fuscans on Phaseolus vulgaris (bean). Page 7021-1-20 in: International Rules for Seed Testing Annexe to Chapter 7: Seed Health Testing Methods. International Seed Testing Association (ISTA), Bassersdorf, Switzerland.

Han, S., Jiang, N., Lv, Q., Kan, Y., Hao, J., Li, J., and Luo, L. 2018. Detection of Clavibacter michiganensis subsp. michiganensis in viable but nonculturable state from tomato seed using improved qPCR. PLoS One 13:e0196525.

Hodgetts, J., Hall, J., Karamura, G., Grant, M., Studholme, D. J., Boonham, N., Karamura, E., and Smith, J. 2015. Rapid, specific, simple, in-field detection of Xanthomonas campestris pathovar musacearum by loop-mediated isothermal amplification. J. Appl. Microbiol. 119:1651-1658.

Huang, W., Zhang, H., Xu, J., Wang, S., Kong, X., Ding, W., and Feng, J. 2017. Loopmediated isothermal amplification method for the rapid detection of Ralstonia solanacearum phylotype I mulberry strains in China. Front. Plant Sci. 8:76.

Jun-hai, N., Yue-rong, G., Jun-mei, Y., Qing-yun, L., Guang-sui, Y., Cun, W., and Yu, R. 2015. Development and evaluation of a loop-mediated isothermal amplification assay for rapid detection of bacterial blight pathogen (Xanthomonas axonopodis pv. dieffenbachiae) in anthurium. Eur. J. Plant Pathol. 142:801-813.

Kado, C., and Heskett, M. 1970. Selective media for isolation of Agrobacterium, Corynebacterium, Erwinia, Pseudomonas and Xanthomonas. Phytopathology 60:969-976.

Kaneko, H., Kawana, T., Fukushima, E., and Suzutani, T. 2007. Tolerance of loopmediated isothermal amplification to a culture medium and biological substances. J. Biochem. Biophys. Methods 70:499-501.

Lang, J. M., Langlois, P., Nguyen, M. H. R., Triplett, L. R., Purdie, L., Holton, T. A., Djikeng, A., Cruz, C. M. V., Verdier, V., and Leach, J. E. 2014. Sensitive detection of Xanthomonas oryzae pathovars oryzae and oryzicola by loop-mediated isothermal amplification. Appl. Environ. Microbiol. 80: 4519-4530.

Larrea-Sarmiento, A., Dhakal, U., Boluk, G., Fatdal, L., Alvarez, A., Strayer-Scherer, A., Paret, M., Jones, J., Jenkins, D., and Arif, M. 2018. Development of a genomeinformed loop-mediated isothermal amplification assay for rapid and specific detection of Xanthomonas euvesicatoria. Sci. Rep. 8:14298.

Lenarčič, R., Morisset, D., Pirc, M., Llop, P., Ravnikar, M., and Dreo, T. 2014. Loopmediated isothermal amplification of specific endoglucanase gene sequence for detection of the bacterial wilt pathogen Ralstonia solanacearum. PLoS One 9:e96027.

Maringoni, A., Kimati, H., and Kurozawa, C. 1994. Variabilidade sorológica entre isolados de Xanthomonas campestris pv. phaseoli. Summa Phytopathol. 20:164-167.

Marques, A. S. A., Guimarães, P. M., Dos Santos, J. P., and Vieira, T. M. 2005. Sobrevivência e viabilidade de Xanthomonas axonopodis pv. phaseoli em sementes de feijão armazenadas sob condições controladas. Fitopatol. Bras. 30:527-531.

Notomi, T., Okayama, H., Masubuchi, H., Yonekawa, T., Watanabe, K., Amino, N., and Hase, T. 2000. Loop-mediated isothermal amplification of DNA. Nucleic Acids Res. 28:e63.

Oliver, J. D. 2005. The viable but nonculturable state in bacteria. J. Microbiol. 43: 93-100.

Palacio-Bielsa, A., López-Soriano, P., Bühlmann, A., Van Doorn, J., Pham, K., Cambra, M. A., Berruete, I. M., Pothier, J. F., Duffy, B., and Olmos, A 2015. Evaluation of a real-time PCR and a loop-mediated isothermal amplification for detection of Xanthomonas arboricola pv. pruni in plant tissue samples. J. Microbiol. Methods 112:36-39.

Paradela Filho, O., Carvalho, A., and Pompeu, A. 1967. Occurrence of Xanthomonas phaseoli var. fuscans (Burk.) Starr \& Burk, in dry beans in the State of São Paulo. Bragantia 26:1-5.

Poole, C. B., Li, Z., Alhassan, A., Gueling, D., Diesburg, S., Tanner, N. A., Zhang, Y., Evans Júnior, T. C., La Barre, C., Wanji, S., Burton, R. A., and Carlow, C. K. S. 2017. Colorimetric tests for diagnosis of filarial infection and vector surveillance using non-instrumented nucleic acid loop-mediated isothermal amplification (NINA-LAMP). PLoS One 12:e0169011.

Rademaker, J., Louws, F., Schultz, M., Rossbach, U., Vauterin, L., and de Brujin, F. J. 2005. A comprehensive species to strain taxonomic framework for Xanthomonas. Phytopathology 95:1098-1111.

Rava, C., Zimmermann, M., Rocha, M., and Yamada, T. 1988. Crestamento bacteriano comum. Pages 420-443 in: Cultura do feijoeiro: fatores que afetam a produtividade. R. S. Araújo, C. Rava, L. F. Stone, and M. J. O. Zimmerman, eds. Associação Brasileira para Pesquisa da Potassa e do Fosfato, Piracicaba, São Paulo, Brasil.

Robbs, C. 1954. A bacteriose do feijoeiro (Phaseolus vulgaris L.) no Distrito Federal. Agronomia 12:445-448.

Ryu, E. 1940. A Simple method of differentiation between gram-positive and gram-negative organisms without staining. Kitasato Arch. Exp. Med. 17:58-63.

Schaad, N. W., Jones, J. B., and Chun, W. 2001. Laboratory Guide for the Identification of Plant Pathogenic Bacteria. Proc. Am. Phytopathol. Soc., St. Paul, MN.

Schaad, N. W., Postnikova, E., Lacy, G. H., Sechler, A., Agarkova, I., Stromberg, P. E., Stromberg, V. K., and Vidaver, A. K. 2005. Reclassification of Xanthomonas campestris pv. citri (ex Hasse 1915) Dye 1978 forms A, B/C/D, and E as $X$ smithii subsp. citri (ex Hasse) sp. nov. nom. rev. comb. nov., X. fuscans subsp. aurantifolii (ex Gabriel 1989) sp. nov. nom. rev. comb. nov., and X. alfalfae subsp. citrumelo (ex Riker and Jones) Gabriel et al., 1989 sp. nov. nom. rev. comb. nov.; X. campestris pv malvacearum (ex Smith 1901) Dye 1978 as X. smithii subsp. smithii nov. comb. nov. nom. nov.; $X$. campestris pv. alfalfae (ex Riker and Jones, 1935) Dye 1978 as X. alfalfae subsp. alfalfae (ex Riker et al., 1935) sp. nov. nom. rev.; and "var. fuscans" of X. campestris pv. phaseoli (ex Smith, 1987) Dye 1978 as X. fuscans subsp. fuscans sp. nov. Syst. Appl. Microbiol. 28:494-518.

Schaad, N. W., Postnikova, E., Lacy G, Sechler, A., Agarkova, I., Stromberg, P. E., Stromberg, V. K., and Vidaver, A. K. 2006. Emended classification of xanthomonad pathogens on citrus. Syst. Appl. Microbiol. 16:690-695.

Tanner, N. A., Zhang, Y., and Evans, E. C., Jr. 2015. Visual detection of isothermal nucleic acid amplification using pH-sensitive dyes. Biotechniques 58:59-68.

Tebaldi, N. D., Souza, R. M., and Machado, J. C. 2007. Detecção de Xanthomonas axonopodis pv. phaseoli em sementes de feijão em meio de cultura semiseletivo. Fitopatol. Bras. 32:56-58.

Temple, T. N., du Toit, L. J., Derie, M. L., and Johnson, K. B. 2013. Quantitative molecular detection of Xanthomonas hortorum pv. carotae in carrot seed before and after hot-water treatment. Plant Dis. 97:1585-1592.

Tomlinson, J., Ostoja-Starzewska, S., Webb, K., Cole, J., Bames, A., Dickinson, M., and Boonham, N. 2013. A loop-mediated isothermal amplification-based method for confirmation of Guignardia citricarpa in citrus black spot lesions. Eur. J. Plant Pathol. 136:217-224.

Toth, I., Hyman, L., Taylor, R., and Birch, P. 1998. PCR-based detection of Xanthomonas campestris pv. phaseoli var. fuscans in plant material and its differentiation from X. c. pv. phaseoli. J. Appl. Microbiol. 85:327-336.

Vieira, C. 1983. Doenças e pragas do feijoeiro. Ed. Viçosa, Viçosa, Minas Gerais, Brazil.

Wang, H., and Turechek, W. 2016. A loop-mediated isothermal amplification assay and sample preparation procedure for sensitive detection of Xanthomonas fragariae in strawberry. PLoS One 11:e0147122. 